https://doi.org/10.46344/JBINO.2021.v010i01.24

\title{
ANTI-INFLAMMATORY AND PROTECTIVE EFFECT OF THE SEED OF TETRACARPIDIUM CONOPHORUM (AFRICAN WALNUT) ON WISTAR RATS WITH DOXORUBICIN INDUCED CARDIOTOXICITY
}

\author{
Ezugwu NS 1*, Anyanwu GE2 ${ }^{2}$ Esom EA² \\ 'Department of Anatomy, Faculty of Basic Medical Sciences, \\ Enugu State University College of Medicine, Parklane, Enugu, Enugu State, Nigeria. \\ 2Department of Anatomy, Faculty of Basic Medical Sciences, \\ College of Medicine, University of Nigeria Nsukka, Enugu, Enugu State, Nigeria.
}

\section{ABSTRACT}

The study investigated the cardioprotective effect of the seed of Tetracarpidium Conophorum extract on wistar rats with doxorubicin-induced myocardial infarction. Herbal drugs are used widely even when their biologically active compounds are unknown, probably because of their effectiveness, lesser side effects and affordability. The result of this study will provide harmless and affordable remedy for cardiotoxicity and other oxidative stress induced diseases. Twenty adult wistar rats $(140-330 \mathrm{~g})$ of both sexes were divided into five experimental groups (A, B, C, D, and E). Each group had four rats. Group A, B, C, D, and E represented groups treated with food only, doxorubicin only, $16 \%$ walnut of feed + doxorubicin), (12\% walnut of feed + doxorubicin) and (Enalapril + doxorubicin) respectively. Cardiotoxicity was induced by the cumulative administration of $15 \mathrm{mg} / \mathrm{kg}$ doxorubicin intraperitoneally during the last alternate seven days $\left(36^{\text {th }}, 38^{\text {th }}, 40^{\text {th }}\right.$ and $\left.42^{\text {nd }}\right)$. After the treatment period of forty-two days, blood samples and hearts were collected for biochemical and histopathological studies respectively. Serum enzyme and lipid profile were checked. There was significant increase $(p<0.05)$ in aspartate transaminase, alanine transaminase, lactate dehydrogenase, creatine kinase, total cholesterol, triglycerides, lowdensity lipoprotein and very low-density lipoprotein with significant decrease $(p<0.05)$ in high-density lipoprotein in the group induced with doxorubicin without additional treatment when compared with the Tetracarpidium Conophorum and Enalapril treated groups. This observation was supported by histopathological report. The repeated administration of doxorubicincaused toxic damage to the myocardium. But treatment with the Tetracarpidium Conophorum significantly protected $(p<0.05)$ the myocardium from the toxic damage. Treatment with Enalapril produced the best abatement, followed by the $12 \%$ walnut of the feed intake.

Key words: Anti-inflammatory, Tetracarpidium conophorum, wistar rats, doxorubicin-induced, toxicity. 


\section{Introduction}

Doxorubicin is an anti-cancer drug that is associated with myocardial infarction (Bai et al., 2017). Despite their extensive use and study, their precise anticancerous mechanism is incomprehensible. Most probably, it is a combination of several different actions, which accounts for the high efficiency of this class of anti-cancer drugs (Ohlig et al. 2018), (Hajra et al., 2018). It might include inhibition of DNA replication by intercalation between the base pairs, which prevents replication of rapidly growing cancer cells. However, contradictory to this, some studies have shown that at clinically relevant anthracycline concentrations, intercalation is unlikely to play a major role and stressed the topoisomerase II as the key target for anthracyclines (Abdel-Daim et al. 2017), (Bai et al., 2017). Doxorubicin is a member of the Anthracycline drug family, and one of the most frequently used anti-tumor agents, having a variety of therapeutic potency against most of the human tumors, including soft tissue sarcoma, breast cancer, small cell carcinoma of the lung and acute leukemias. The present study has investigated the curative ability of Tetracarpidium Conophorum (African Walnut) on the wistar rats with doxorubicin induced myocardial infarction. It is commonly found in the temperate, subsaharan and tropical regions of the world. Phytochemical constituents of Tetracarpidium conophorum include alkaloids, flavonoids, phenols, saponins, tannins, oil, carbohydrates, proteins, vitamins and minerals (Chikezie, 2017 and
Akomolafe et al., 2017d). The nutritional analysis of $T$. conophorum reveals it as a fair source of carbohydrate and fibre with appreciable protein content, but significantly rich in edible and industrially useful oil as well as dependable quantity of essential dietary minerals for both children and adults. The major constituents of the oil are triglycerides, fatty acids, diglycerides, sterols and esters (Barber and ObinnaEchem, 2016).

Herbal drugs are used widely even when their biologically active compounds are unknown, probably because of their effectiveness, lesser side effects and affordability. Today the usage of herbal drugs is gaining wider acceptance in medical practice due to their positive contribution and influence on health. The result of this study will provide harmless and affordable remedy for oxidative stress caused diseases, myocardial infarction due to doxorubicin therapy on cancer patient, hypertension, and other cardiovascular diseases.

\section{Materials and methodology}

Adult wistar rats $(160-300 \mathrm{~g})$ of both sexes were gotten from the animal house of the University of Nigeria teaching hospital, and caged in a well-ventilated animal house of the department of Anatomy, University of Nigeria, Enugu Campus at $25 \pm 5 \circ \mathrm{C}$ under 12:12 hours light \& dark cycle. The animals were divided into five experimental groups (A, B, C, D, and E). Each group had four rats, and were allowed to acclimatize for two weeks before the experiment. The animals had free access to standard rat 
chow (Grower's mash) and water ad libitum. All animal experiments were conducted in compliance with the humane animal care standards outlined in the 'Guide to the care and use of Animals in Research and Teaching' as approved by the Institute of Laboratory Animals Resources National Research Council,
DHHS, Pub. No. NIH 86-123 (1985). Body weights were recorded every week until the end of the experiment.

\section{Experimental protocol}

The animals were divided into five experimental groups ( $A, B, C, D$, and $E)$, as shown below.

\section{Table 1: Experimental protocol}

\begin{tabular}{|c|c|}
\hline GROUPS & EATMENT \\
\hline $\begin{array}{l}\text { A: Food and } \\
\text { water (Negative } \\
\text { control) }\end{array}$ & $\begin{array}{l}\text { Day } 1 \text { to 42: Grower's mash and water ad libitum daily, and normal } \\
\text { saline. }\end{array}$ \\
\hline $\begin{array}{l}\text { B: Doxorubicin } \\
\text { (Positive control) }\end{array}$ & $\begin{array}{l}\text { Day 36, 38, } 40,42: 3.75 \mathrm{mg} / \mathrm{kg} \text { Doxorubicin injection on alternate last } \\
\text { seven days of the experiment. }\end{array}$ \\
\hline $\begin{array}{l}\text { C: } 6 \% \text { walnut of } \\
\text { feed }+ \\
\text { Doxorubicin }\end{array}$ & $\begin{array}{l}\text { Day } 1 \text { to 35: Pretreated with } 6 \% \text { walnut of food intake. } \\
\text { Day 36, 38, 40, 42: } 3.75 \mathrm{mg} / \mathrm{kg} \text { Doxorubicin injection on alternate last } \\
\text { seven days of the experiment. }\end{array}$ \\
\hline $\begin{array}{l}\text { D: } 12 \% \text { walnut } \\
\text { of feed }+ \\
\text { Doxorubicin }\end{array}$ & $\begin{array}{l}\text { Day } 1 \text { to 35: Pretreated with } 12 \% \text { walnut of food intake. } \\
\text { Day 36, 38, 40, 42: } 3.75 \mathrm{mg} / \mathrm{kg} \text { Doxorubicin injection on alternate last } \\
\text { seven days of the experiment. }\end{array}$ \\
\hline $\begin{array}{l}\text { E: Enalapril + } \\
\text { Doxorubicin } \\
\text { (Positive control } \\
\text { group) }\end{array}$ & $\begin{array}{l}\text { Day } 1 \text { to 35: Pretreated with } 0.64 \mathrm{mg} / \mathrm{kg} \text { Enalapril. } \\
\text { Day 36, 38, 40, 42:3.75mg/kg Doxorubicin injection on alternate last } \\
\text { seven days of the experiment. }\end{array}$ \\
\hline
\end{tabular}

\section{Doxorubicin}

All drugs and reagents used in this study were of analytical grade. Doxorubicin was obtained from Olive Pharmacy, Trans-Ekulu Enugu, Enugu State of Nigeria.
Reconstitution: 50mg Lyophilized powder was reconstituted with $10 \mathrm{ml}$ Sterile Water for Injection to give a final concentration of $5 \mathrm{mg} / \mathrm{ml}$. 
Dosage: $\quad 3.75 \mathrm{mg} / \mathrm{kg}$ body weight doxorubicin was administered for alternated four days through intraperitoneal route, which constituted the cumulative dose of $15 \mathrm{mg} / \mathrm{kg}$ body weight that causes myocardial infarction (Shakya Manish et al., 2011).

Storage/Stability:Intact vials (lyophilized powder) and reconstituted solution was kept stable for $\leq 15$ days under refrigeration $\left(2^{\circ}\right.$ to $8^{\circ} \mathrm{C} /$ or $36^{\circ}$ to $\left.46^{\circ} \mathrm{F}\right)$ and was also protected from light.

\section{Enalapril}

Enalapril was obtained from Olive Pharmacy, Trans-Ekulu Enugu, Enugu State of Nigeria.

Administration: Oral administration.

Dosage: $0.64 \mathrm{mg} / \mathrm{kgENA}$ was administered to the experimental rats (Ma Hongbao and Yang Yan,2015).

\section{Walnut (Tetracarpidium conophorum)}

Fresh walnut pod was obtained from walnut plantation at Opi, Nsukka Local Government Area, Enugu State of Nigeria. A specimen of the walnut was identified by a botanist from Department of Plant Science and Biotechnology, University Of Nigeria, Nsukka, with herbarium voucher specimen number $377 a$. The nuts were boiled at $100^{\circ} \mathrm{C}$ for 2 hours. It was then allowed to cool. The shells were removed and the milky coloured nuts were dried. The dried nuts were made into powder with mechanical grinder. The powder was formulated into feed with grower's mash in
$6 \%$ and $12 \%$ weight of feed intake concentration in accordance to Ghorbani et al., 2014 and Ebrahim et al., 2012, and some other researchers' design on animal experiment with walnut.The mix ratio was calculated thus:

The percentage $:(100-$ The percentage $)=$ $6 \%:(100-6 \%)=6: 94=$ Walnut $:$ Feed .

$-12 \%)=12: 88=$ Walnut $:$ Feed.

$$
=12 \%:(100
$$

$\therefore$ Weight of walnut to be mixed with feed

$$
=\frac{\% \text { Walnut of feed intake } \mathbf{X} \text { Weight of } \mathrm{fe}}{100-\% \text { Walnut of } \mathrm{fe}}
$$

\section{Phytochemical analysis of the boiled walnut seed}

The presence of phytochemical constituents in the aqueous extract ofwalnut (tetracarpidium conophorum) was evaluated at Brainphosphorylationship scientific solution services, Ogui road, Enugu. Extract was tested for the presence of the following bioactive substances: alkaloid, saponins (Harborne, 1996), (Harborne, 2005), flavonoids (Sofowora, 1982), phenolic content (Lin and Tang, 2007), Test for tannins (Trease and Evans, 2002).

\section{Biochemical and histological studies}

After 42 days of the experimental period, the animals were anaesthesised under mild chloroform anaesthetic. The blood samples were collected immediately for biochemical assay, and the heart tissues were quickly harvested, washed in icecold saline, dried on filter paper, and fixed in $10 \%$ formol-saline for histological procedures. 


\section{Biochemical studies:}

Serum collected wasseparated by centrifuging for $10,000 \mathrm{rvp}$ for $20 \mathrm{~min}$. The activities of serum aspartate transaminase and alanine transaminase were respectively determinedcolorimetrically and spectrophotometrically by the method of(Tietz, 1995). The creatine phosphokinase (CPK) and lactate dehydrogenase (LDH)were also determined by the methods of (Tietz, 1995). The levels of totalCholesterol, triglycerides (TGs), and serum high density lipoprotein (HDL) wereestimated by the methods of (Belcher et al., 1991).Serum low density lipoproteins (LDL) andvery low density lipoproteins (VLDL) werecalculated as LDL $=$ total cholesterol - (HDL cholesterol +
VLDL cholesterol) and VLDL=triglycerides/5 respectively.

Histological studies:The hearts were removed, washed immediately with saline and then fixed in $10 \%$ formal saline. The hearts fixedin $10 \%$ formal saline were embedded inparaffin, sections cut at 5 $\mathrm{mm}$ and stained with hematoxylin and eosin. These sectionswere then examined under a lightdigital microscope for histoarchitectural changes.

\section{Statistics}

SPSS for Windows version 21 was used, and all results were reported as mean values \pm standard deviation (SD). Descriptive statistics were done for all the variables in the various groups with a paired samples test, and $(p<0.05)$ was considered statistically significant

\section{Results}

Phytochemical result of the boiled seed of $T$. Conophorum

Table 2: Phytochemical result of the boiled dried seed of Tetracarpidium conophorum

\begin{tabular}{|l|l|l|}
\hline Constituents & Bioassay & $\mathbf{M g} / \mathbf{g}$ \\
\hline Alkaloids & + & 1.545 \\
\hline Flavonoids & ++ & 5.801 \\
\hline Phenols & + & 2.620 \\
\hline Saponins & +++ & 11.415 \\
\hline Tannins & + & 0.689 \\
\hline
\end{tabular}

\section{General observation on the animals}

There was no death in the group fed with only grower's mash and groups treated with Tetracarpidium conophorum. However, a mortality rate of $25 \%$ occured in doxorubicin-induced myocardial toxicity group. Doxorubicin treated group also showed decrease in the feed and water intake during the drug treatment period when compared with other groups. 
Results on the biochemical test

Table 3 and fig. 1 show mean serum enzyme level.The level of the serum enzyme (CK-MB, ALT, AST and LDH) significantly decreased $(p<0.05)$ in the group treated

Tetracarpidiumconophorum with compared with the group treated with doxorubicin. Pretreatment with $T$. conorphorum significantly decreased $(p<$ 0.05 )this serum marker enzyme.Also, the level of the serum enzyme significantly decreased $(p<0.05)$ in the group treated with Enalaprilwhen compared with the group treated with doxorubicin.There was no significant increase $(p>0.05)$ in the group treated with $12 \%$ walnutof the feed intake when compared to the Enalapril.There was no significant increase $(p>0.05$ ) in the group treated with $12 \%$ walnutof the feed intakewhen compared with the group fed with grower's mash only.

Table 3: Mean Rat Serum enzyme

\begin{tabular}{|c|c|c|c|c|}
\hline TREATMENT & $\begin{array}{l}\text { CK-MB } \\
(1 \mu / L)\end{array}$ & $\begin{array}{l}\text { ALT } \\
(\mu / L)\end{array}$ & $\begin{array}{l}\text { AST } \\
(1 \mu / \mathrm{L})\end{array}$ & $\begin{array}{l}\text { LDH } \\
(\mu / \mathrm{L})\end{array}$ \\
\hline $\begin{array}{l}\text { A: Positive } \\
\text { control : Food } \\
\text { only }\end{array}$ & $157.11 \pm 5.94$ b D & $48.00 \pm 4.41^{\mathbf{b ~ D}}$ & $66.19 \pm 8.63^{\text {b D }}$ & $109.58 \pm 11.48^{\mathbf{b} \mathbf{D}}$ \\
\hline $\begin{array}{l}\text { B: Negative } \\
\text { control : DOX } \\
\text { only }\end{array}$ & $387.70 \pm 16.41^{\mathrm{ad}}$ & $77.05 \pm 7.45^{\mathrm{a} \mathrm{d}}$ & $197.20 \pm 8.36^{\mathbf{a d}}$ & $205.30 \pm 16.80^{\mathbf{a} \mathbf{d}}$ \\
\hline $\begin{array}{l}\text { C: DOX }+6 \% \\
\text { walnut of feed }\end{array}$ & $\begin{array}{l}265.21 \pm 13.44^{\mathrm{a}} \mathrm{b} \\
\mathrm{d}\end{array}$ & $\begin{array}{l}57.86 \pm 8.51^{\mathrm{A} \mathrm{B}} \\
\text { D }\end{array}$ & $87.32 \pm 3.39^{\mathbf{b}}$ A D & $167.61 \pm 20.04^{\mathbf{b}} \mathrm{A}$ \\
\hline $\begin{array}{l}\text { D: DOX }+12 \% \\
\text { walnut of feed }\end{array}$ & $\begin{array}{l}251.23 \pm 10.04^{\mathbf{b}} \mathbf{A} \\
\mathbf{D}\end{array}$ & $54.21 \pm 5.57^{\mathbf{b}} \mathbf{A} \mathbf{D}$ & $76.14 \pm 8.63^{\mathrm{b} A ~ D}$ & $\begin{array}{l}161.42 \pm 18.57^{\mathbf{b}} \mathbf{A} \\
\text { D }\end{array}$ \\
\hline $\begin{array}{l}\text { E: DOX } \\
\text { Enalapril }\end{array}$ & $161.41 \pm 8.06^{\mathbf{b ~ A}}$ & $\begin{array}{l}62.13 \pm 10.07 \quad \text { b } \\
\text { A }\end{array}$ & $72.51 \pm 3.54^{\mathbf{b ~ A}}$ & $112.11 \pm 17.20^{\mathbf{b A}}$ \\
\hline
\end{tabular}

Values are mean $\pm \mathrm{SD} ; \mathbf{n}=\mathbf{4}$ in each group, $(\mathbf{p}<\mathbf{0 . 0 5})=$ Statistically significant. 
$\mathbf{a}=$ Significant when compared with the positive control $(\mathbf{A}), \mathbf{b}=$ Significant when compared with the negative control (B), $\mathbf{d}=$ Significant when compared with the standard drug $(\mathbf{E}), \mathbf{A}=$ Not significant when compared to the positive control (A), B = Not significant when compared with the negative control $(\mathbf{B}), \mathbf{D}=$ Not significant when compared with the standard drug (E).

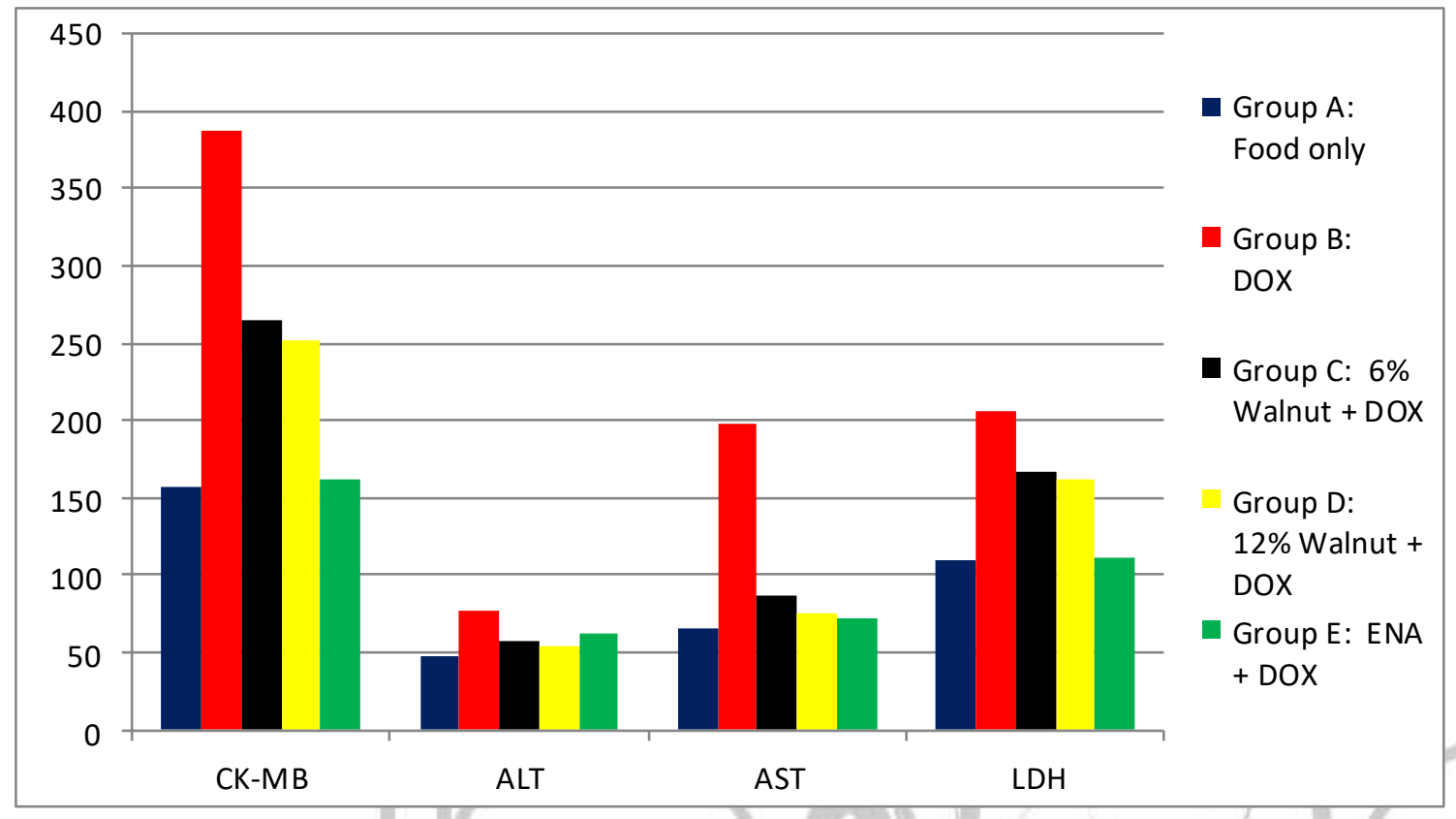

Fig. 1: Component bar graph showing serum marker enzyme level

Table 3 and fig. 2 show mean plasma lipid profile level. There was significant decrease $(\mathrm{p}<0.05)$ in the level of the CHOL, TRI, LDL and VLDL with increased HDL in the group treated with Tetracarpidium conophorum when compared with the group treated with doxorubicin. There was no significant increase $(\mathrm{p}>0.05)$ in the level of the CHOL, TRI, LDL and VLDL with decreased HDL in the group treated with Tetracarpidium conophorum when compared withEnalapril.But pretreatment with Tetracarpidium conorphorum (Walnut) before DOX-induced myocardial infarction significantly ( $p>0.05$ ) decreased the level of CHOL, TRI, LDL and VLDL with increased HDL.Also, there was no significant $(\mathrm{p}>0.05)$ increase in the level of the CHOL, TRI, LDL and VLDL with decreased HDL in the group treated with Tetracarpidium conophorum when compared with the group fed with grower's mash only. 
Table 4: Mean Rat Lipid profile

\begin{tabular}{|c|c|c|c|c|c|}
\hline $\begin{array}{l}\text { TREAT- } \\
\text { MENT }\end{array}$ & $\begin{array}{l}\text { CHOL } \\
\text { (mg/dl) }\end{array}$ & TRI (mg/dl) & $\begin{array}{l}\text { HDL } \\
\text { (mg/dl) }\end{array}$ & LDL (mg/dl) & $\begin{array}{l}\text { VLDL } \\
\text { (mg/dl) }\end{array}$ \\
\hline $\begin{array}{l}\text { A: Positive } \\
\text { control: Food } \\
\text { only }\end{array}$ & $\begin{array}{l}105.23 \pm \\
2.40^{\mathbf{b ~ D}}\end{array}$ & $\begin{array}{l}49.11 \pm \\
2.99^{\mathrm{b}} \mathrm{D}\end{array}$ & $\begin{array}{l}41.17 \pm \\
8.65^{\text {B D }}\end{array}$ & $\begin{array}{l}29.80 \pm \\
4.89^{\mathbf{b} d}\end{array}$ & $\begin{array}{l}19.14 \pm \\
1.36^{\mathrm{b} \mathrm{D}}\end{array}$ \\
\hline $\begin{array}{l}\text { B: Negative } \\
\text { control: DOX } \\
\text { only }\end{array}$ & $\begin{array}{l}145.21 \pm \\
5.09^{\mathrm{a} \mathrm{d}}\end{array}$ & $\begin{array}{l}79.19 \pm \\
1.80^{\text {a d }}\end{array}$ & $\begin{array}{l}32.73 \pm \\
5.53^{\mathrm{d} A}\end{array}$ & $\begin{array}{l}76.49 \pm \\
9.80^{\text {a d }}\end{array}$ & $\begin{array}{l}35.99 \pm \\
0.82^{\mathbf{a ~ d}}\end{array}$ \\
\hline $\begin{array}{l}\text { C: DOX }+6 \% \\
\text { walnut of feed }\end{array}$ & $\begin{array}{l}130.7 \pm \\
11.46^{\mathbf{a d ~ B}}\end{array}$ & $\begin{array}{l}71.05 \pm \\
5.81^{\mathbf{a} d \mathbf{~ B}}\end{array}$ & $\begin{array}{l}35.2 \pm \\
1.56^{\mathbf{A}} \mathbf{B} \mathbf{D}\end{array}$ & $\begin{array}{l}69.75 \pm \\
7.26^{\mathbf{a d ~ B}}\end{array}$ & $\begin{array}{l}32.75 \pm \\
2.64^{\mathrm{a}} \text { B D }\end{array}$ \\
\hline $\begin{array}{l}\text { D: DOX + } \\
12 \% \text { walnut } \\
\text { of feed }\end{array}$ & $\begin{array}{l}115.25 \pm \\
5.78^{\text {b A D }}\end{array}$ & $\begin{array}{l}60.01 \pm \\
5.57^{\text {b A D }}\end{array}$ & $\begin{array}{l}39.14 \pm \\
0.14^{\text {b A D }}\end{array}$ & $\begin{array}{l}53.83 \pm \\
3.39^{\mathbf{b}} \mathbf{A} \text { D }\end{array}$ & $\begin{array}{l}27.28 \pm \\
2.53^{\text {b A D }}\end{array}$ \\
\hline $\begin{array}{l}\text { E: DOX } \\
\text { Enalapril }\end{array}$ & $\begin{array}{l}108.41 \pm \\
8.06^{\mathbf{b}} \mathbf{A}\end{array}$ & $\begin{array}{l}51.13 \pm \\
10.07^{\mathbf{b} A}\end{array}$ & $\begin{array}{l}39.51 \pm \\
3.54^{\mathbf{b A}}\end{array}$ & $\begin{array}{r}45.66 \pm \\
0.06^{\mathbf{b} A}\end{array}$ & $\begin{array}{l}23.24 \pm \\
4.58^{\mathbf{b} A}\end{array}$ \\
\hline
\end{tabular}

Values are mean $\pm \mathrm{SD} ; \mathbf{n}=\mathbf{4}$ in each group, $(\mathbf{p}<\mathbf{0 . 0 5})=$ Statistically significant.

$\mathbf{a}=$ Significant when compared with the positive control (A), $\mathbf{b}=$ Significant when compared with the negative control $(\mathbf{B}), \mathbf{d}=$ Significant when compared with the standard drug $(\mathbf{E}), \mathbf{A}=$ Not significant when compared with the positive control (A), B = Not significant when compared with the negative control $(\mathbf{B}), \mathbf{D}=$ Not significant when compared with the standard drug (E). 


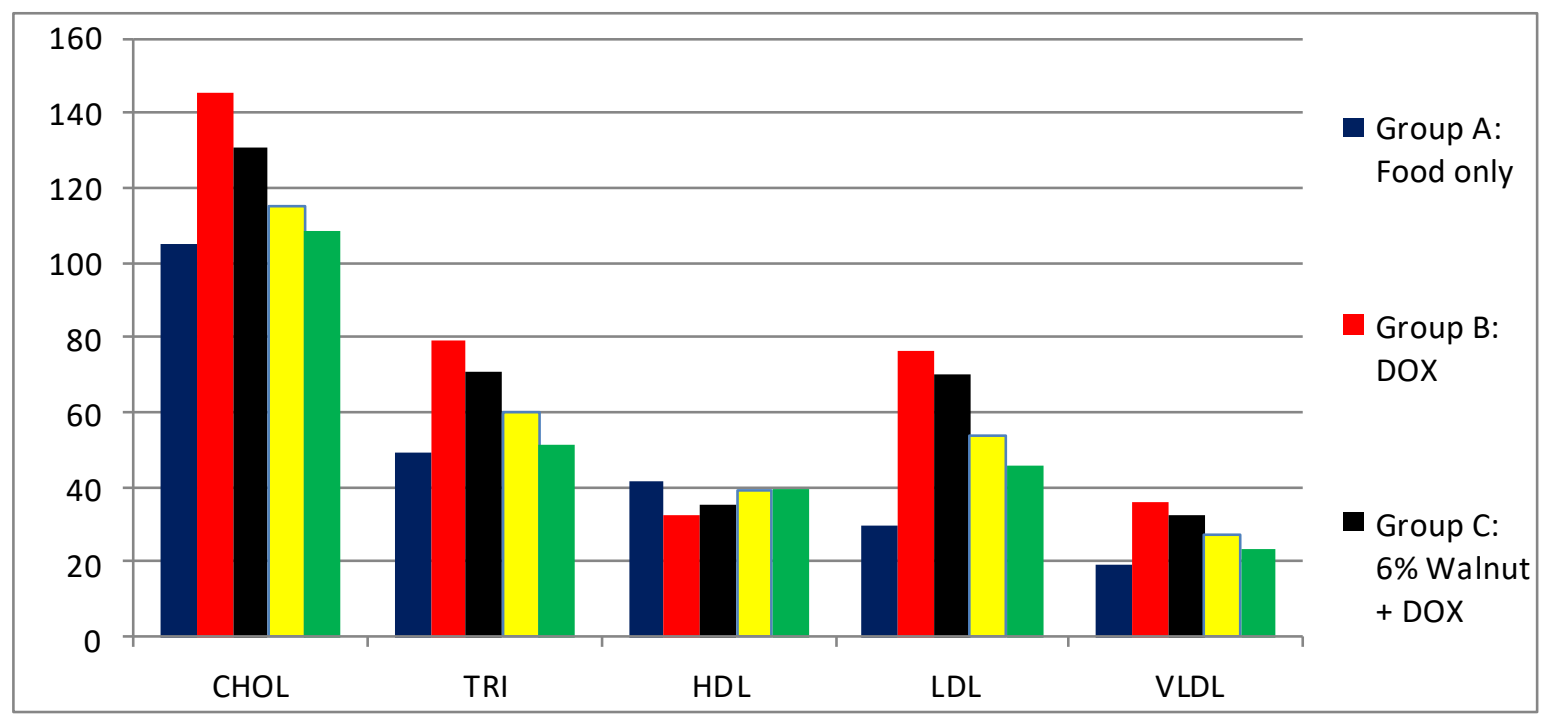

Fig. 2: Component bar graph showing lipid profile level

\section{Histographs}

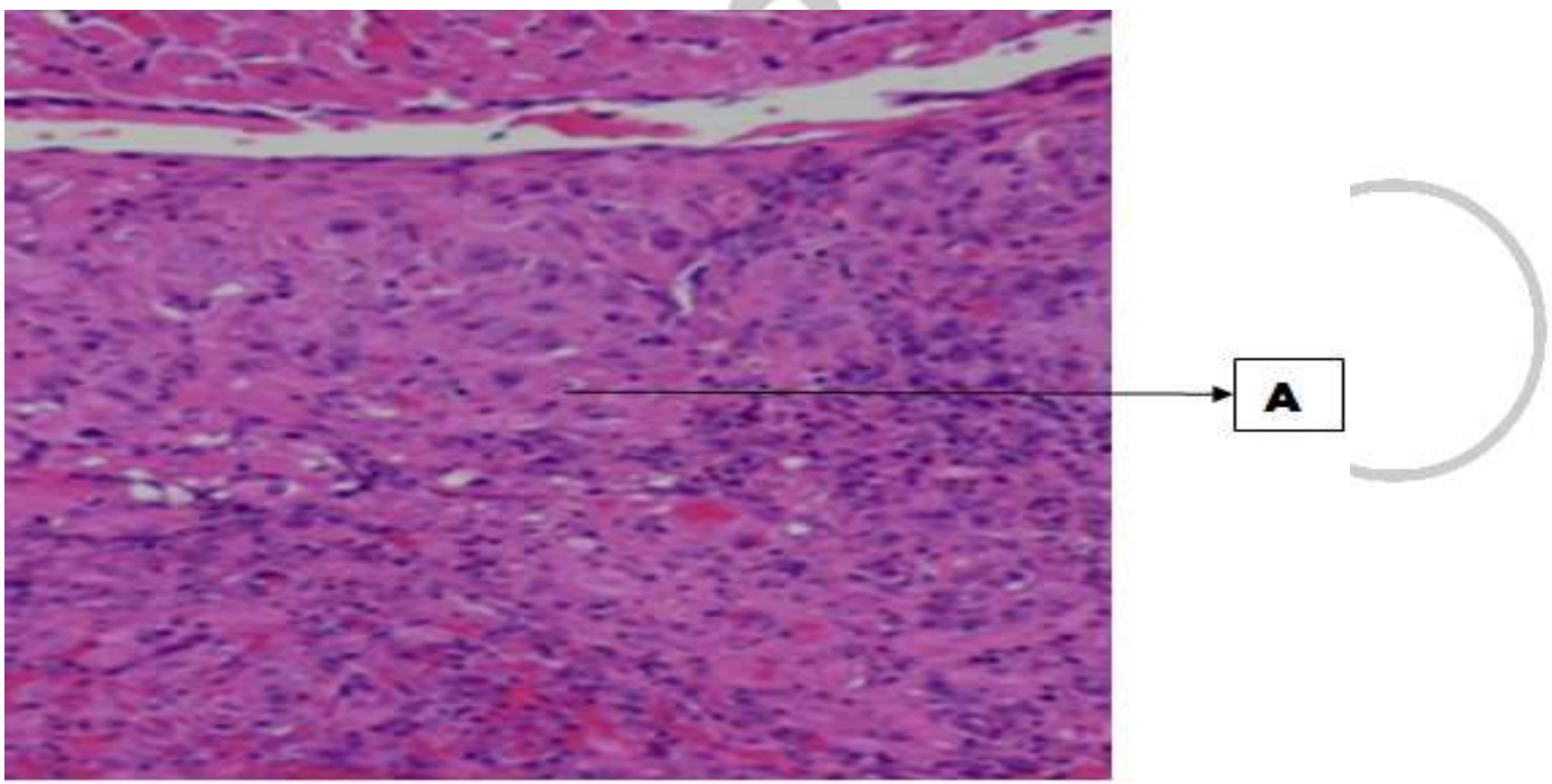

PLATE 1: Showing the heart of the rat treated with only growers mash. A, normal myocardial architecture (H\&E x 100) 


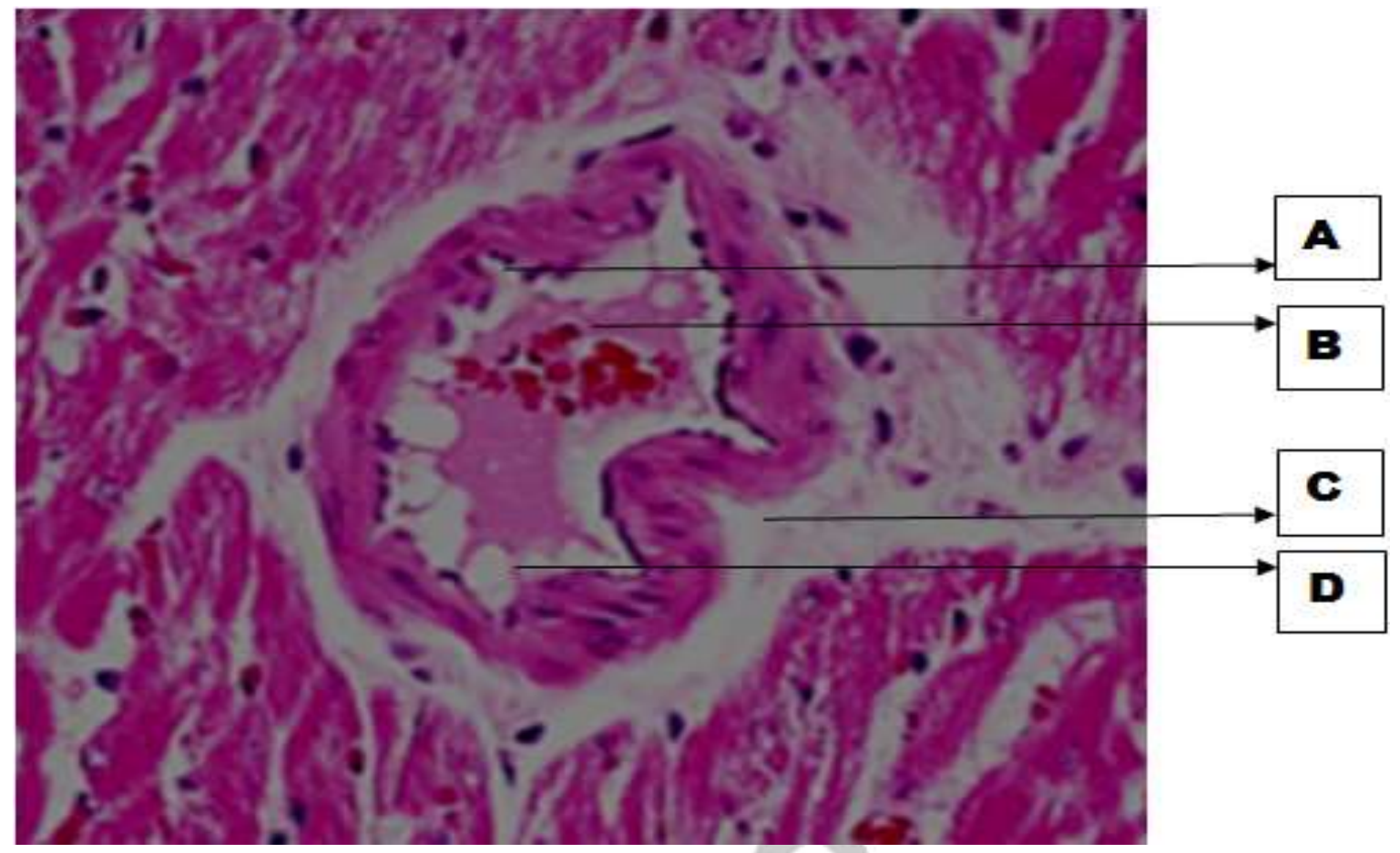

PLATE 2: Showing the heart of the rat treated with only doxorubicin. A, patchy intimal ulceration, B, luminal stenosis and obstruction, $\mathbf{C}$, myocardiac cell degeneration around the constricted blood vessel, $\mathbf{D}$, asymmetrical medial hypertrophy (H\&E x 400)

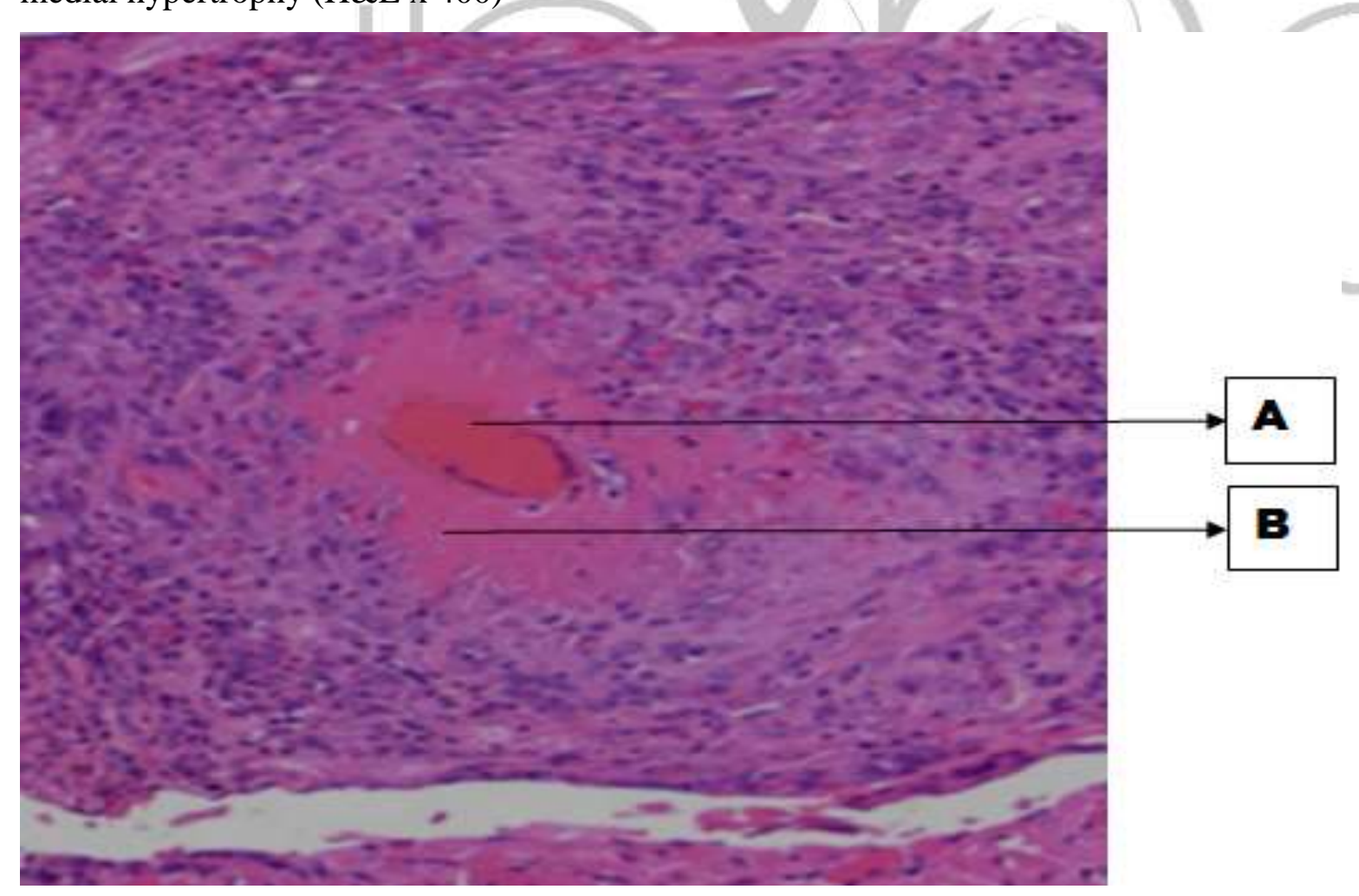

PLATE 3:Showing the heart of the rat pretreated with $6 \%$ walnut of the feed intake, and later with doxorubicin.A, mild coronary vascular congestion and $\mathbf{B}$, mild media hypertrophy (H\&E x 400) 


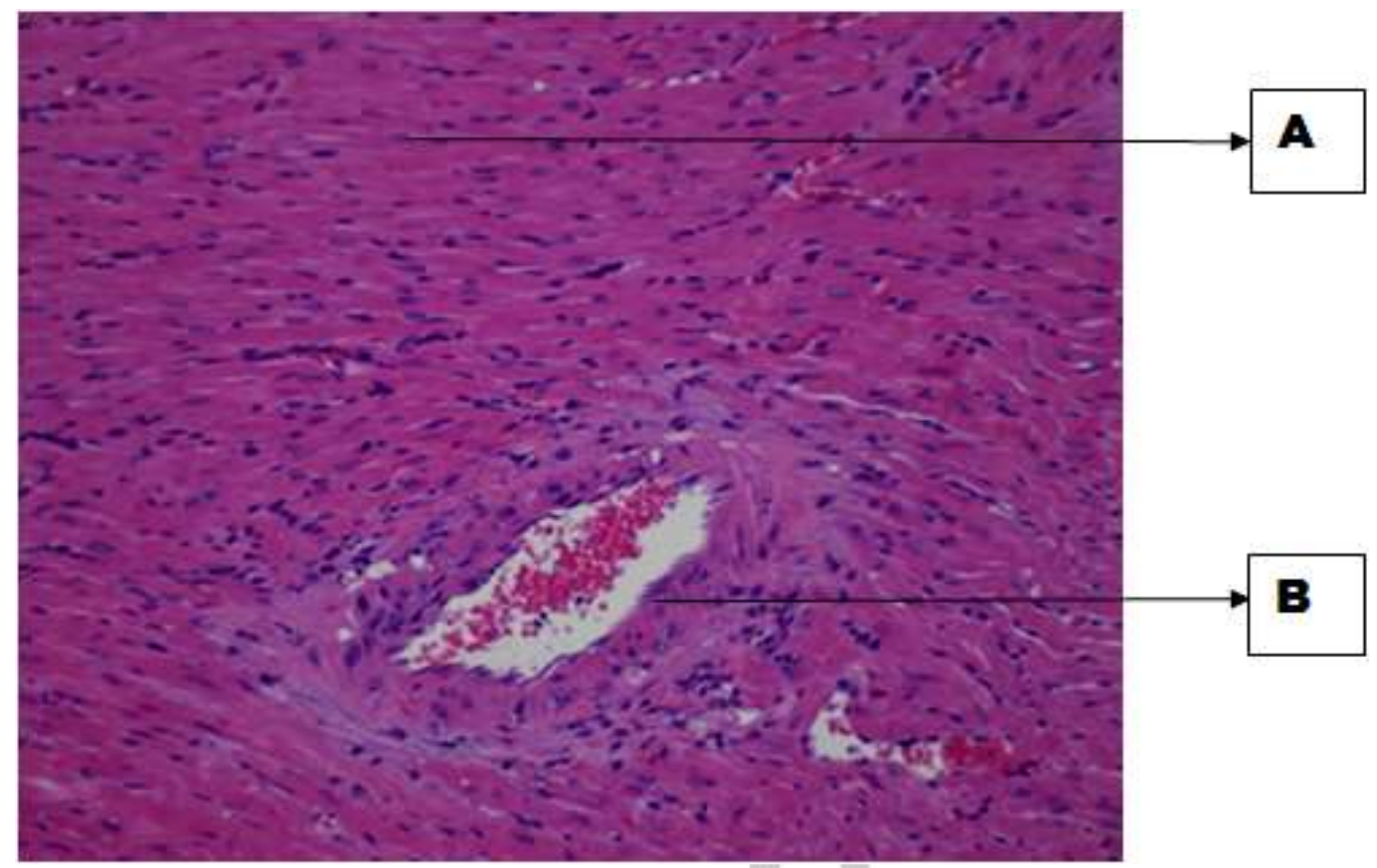

PLATE 4:Showing the heart of the rat pretreated with $12 \%$ walnut of the feed intake, and later with doxorubicin. A, normal myocardiac architecture, B, normal vascular dilatation (H\&E x 100)

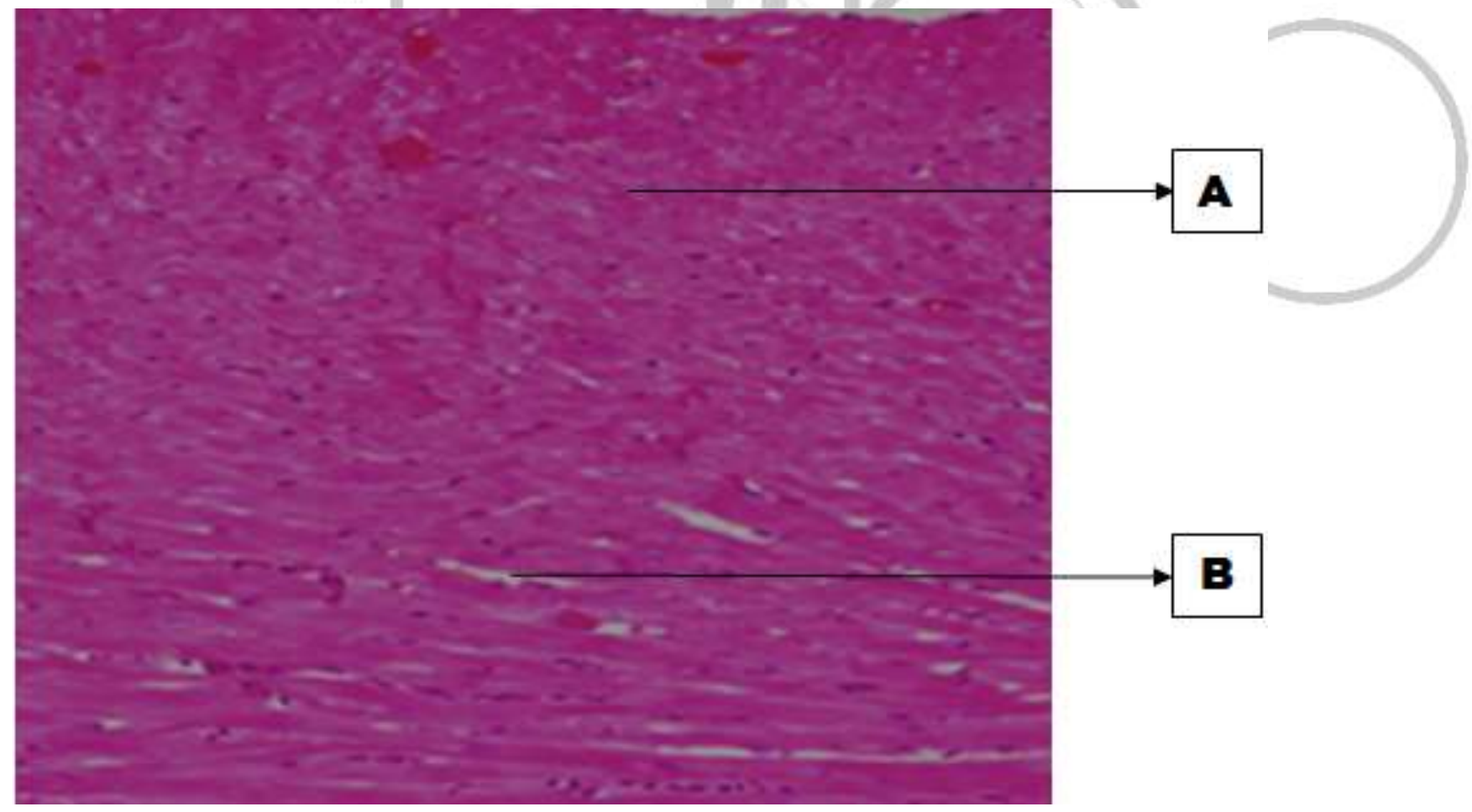

PLATE 5: Showing the heart of the rat pretreated with Enalapril, and later with doxorubicin. A, normal myocardiac fibre/architecture, B, interstitial space (H\&E x 100)

\section{Discussion}

Oxygen-free radicals generated during doxorubicin redox cycling are responsible 
for the damage that doxorubicin causes to the heart (Chen et al., 2011).Chen et al., 2011 and many other researchers reported that there is leakage of diagnostic marker enzyme in the serum when there is myocardial infarction, which served as a diagnostic marker.The decreased level of the serum marker enzyme in the walnut treated group with no animal death when compared with the doxorubicin indicates that the walnut extract has the potential that may have protected the heart from the infarction. This is in accordance with Akomolafe et al., (2015) and Amaeze et al., (2011) report on the anti-oxidative activity of walnut extract.Abid Elbaky et al., 2010 and Chen et al., 2011 reported that decreased level of serum marker enzyme has a negative correlation with myocardial infarction and increased level has a positive correlation. The close level of the serum marker enzyme in the walnut treated group when compared with Enalapril indicates that the walnut extract has potential that may have protected the heart from the infarction. Also when compared to the positive control group fed with only grower's mash.The administration of Tetracarpidium conorphorum (Walnut) significantly may have prevented myocardial infarction as evidenced by the decreased level of $\mathrm{CHOL}, \mathrm{TRI}, \mathrm{LDL}$ and VLDL with increased level of $\mathrm{HDL}$ when compared with the doxorubicin group. The increased concentration of cholesterol could be due to a decrease in $\mathrm{HDL}$, since $\mathrm{HDL}$ is involved in the transport of cholesterol from tissues to the liver for its catabolism. The observed increase in CHOL, TRI, LDL, VLDL might be due to a decrease in the activity of lipoprotein lipase, which resulted to decreased uptake of triglyceride from the circulation. Shakya Manish et al., 2011 reported that myocardial infarction is associated with altered lipid metabolism.Shakya Manish et al., 2011 and Onwuli et al., 2014 showed in their Studies that high level of CHOL, TRG, LDL, and VLDL cholesterol has a positive correlation with myocardal infarction, whereas high level of HDL cholesterol has a negative. In this context, we have observed decreased levels of HDL in doxorubicin-treated group and increased level in walnut treated group, which shows that the walnut may have protected the heart from the myocardial infarction.

Histopathological report suggested thatTetracarpidium conorphorum (Walnut) may have protected the heart from myocardial infarction, as the heart showed normal appearance, with no inflammatory cell infiltration, and no myocardial fibre degeneration, patchy intimal ulceration, and luminal stenosis and obstruction in the group treated with $T$. Conorphorum. Cardiomyopathy occurred in the doxorubicin treated group, as seen in the micrograph.Infarction occurred in the doxorubicin treated rats, as illustrated by the appearance of myocardial cell degeneration, asymmetrical medial hypertrophy, patchy intimal ulceration, and luminal stenosis and obstruction in the micrograph. Doxorubicin produced massive pathological changes in the myocardium, showing a varying degree of vacuolar damages in the cardiac muscle fibers mainly in the form of 
degeneration/necrosis of myocardial tissue or myofibrillar loss, vacuolization of the cardiomyocytes, and infiltration of inflammatory cells.But pretreatment with the standard drug, Enalapril produced the most remarkable

(best) abatement,followed by $12 \%$ walnut extract of the feed intake.

\section{Conclusion}

The experimental studies revealed biochemical changes in the serum as well as histological changes after doxorubicininduced myocardial infarction in the wistar rats. But pretreatment with Tetracarpidium conorphorum showed prevention from doxorubicin-induced myocardial infarction. The administration of Tetracarpidium conorphorum (Walnut) before doxorubicin-induced myocardial toxicity showed prevention from doxorubicin-induced elevated serum marker enzymes. This confirms that Tetracarpidium conorphorum (Walnut) is responsible for the maintenance of normal structural and/or architectural integrity of cardiac tissue/myocytes through protecting the heart from the myocardial infarction. This ultimately restricted the leakage of the diagnostic marker enzyme in the serum, which can be accounted for the membrane stabilizing property of Tetracarpidium conorphorum (Walnut).

\section{Recommendation}

Herbal drugs are widely used even when their biologically active compounds are unknown, probably because of their effectiveness, lesser side effects and affordability. Tetracarpidium Conophorum is cheap and readily available in Africa, with no side effect. It contains omega-3essential (polyunsaturated) fatty acids, which has been implicated in the normal cardiovascular function (Nwaichi et al., 2017). High content of ascorbic acid in the seed (walnut)also indicates that it can prevent, or minimize the formation of carcinogenic substances from dietary material (Chikezie, 2017). This solves the problem (myocardial infarction) created by the doxorubicin during cancer treatment, and equally helps doxorubicin to perform its task of cancer management. Our study suggests that Tetracarpidium conorphorum (walnut) should be considered as a potential safe, useful and affordable substance to limit free radical mediated organ injury like myocardial infarction, especially in cancer patients undergoing treatment with anthracyclines like doxorubicin, and other pharmacologically related therapy. Meanwhile, it is worthwhile to consider this aspect for clinical application in cancer patients at risk of cardiac injury due to doxorubicin therapy, people that are hypertensive, and other people at the risk of cardiovascular diseases. The search for new interventional targets will continue to depend on the knowledge of basic pathophysiological mechanisms based on relevant preclinical models. Further molecular level of investigation should be done using different animal models and different biochemical parameters, so as to assess the possible mode of action of the seed of Tetracarpidium conorphorum (Walnut) as cardioprotective agent, which will help in the modeling of a new drug for various diseases. 


\section{References}

Abdel-Daim, M.M., OE. Kilany, H.A. Khalifa, AAM. Ahmed (2017) Allicin ameliorates doxorubicin-induced cardiotoxicity in rats via suppression of oxidative stress, inflammation and apoptosis. Cancer Chemother Pharmacol 80: 745-753.

Abid Elbaky NA, Ali AA, Ahmed RA (2010). Cardioprotective effect of simvastatin on doxorubicin-induced

oxidative

cardiotoxicity in rats. Journal of Basic and Applied Sciences; 6(1):29-38.

Ahmad S, Panda BP, Fahim M, (2018). Ameliorative effect of beraprost sodium on celecoxib induced cardiotoxicity in rats. Iran J Pharm Res., 17 (1) (2018), p. 155.

Ahmed, Q, Gupta, N, Kumar A, Nimesh, S. (2017). Antibacterial efficacy of silver nanoparticles synthesized employing Terminalia arjuna bark extract. Artif Cells Nanomed Biotechnol. 2017:45(6):11921200.

Ajaiyeoba EO and Fadare DA (2006). "Antimicrobial potential of extracts and fractions of the African walnut (Tetracarpidium conophorum)".Afr J Biotechnol., 5(22): 2322 -2326.

Akomolafe, SF \& Oboh, G, 2017b, 'Walnut leaf extract acts as a fertility agent in male Wistar albino rats - A search for herbal male fertility enhancer', Journal of Complementary and Integrative Medicine 1-14. https://doi.org/10.1515/jcim-20170076.
Akomolafe, SF, Oboh, G, Akindahunnsi, AA, Afolayan, AJ, 2015C, 'T. Conophorum (Mull. Arg) Hutch and Dalziel inhibit $\mathrm{FeSO}_{4}$ induced lipid peroxidation in rats genital', BMC Complementary and Alternative Medicine 15(57), 1-11.

Akomolafe, S.F., Oboh, G., Oyeleye, S.I. \& Olasehinde, T.A., 2017d, 'Toxicological effects of aqueous extract from African walnut (Tetracarpidium conophorum) leaves in rats', Journal of Evidence-Based Complementary \& Alternative Medicine 22(4), 919-925. https://doi.org/10.1177/2156587217718979.

Amaeze UO, Ayoola GA, Sodiya MO, Adepoju-Bello AA, Adegoke $\mathrm{AO}$ and Coker HAB (2011). "Evaluation of antioxidant activity of Tetracarpidium conophorum (Mull. Arg) Hutch \& Dalziel leaves", Oxidative Med Cell Long., 13: 1 -7.

Awada HK, Johnson NR, Wang Y, (2015). Sequential delivery of angiogenic growth factors improves revascularization and heart function after myocardial infarction. J Control Release. 2015;207:7-17.

Ayodele OB (2003). Nutrition in Nigeria Ibadan. Catoon Publishers, USA.

Bai Y, Chen Q, Sun YP, (2017). Sulforaphane protection against the development of doxorubicin-induced chronic heart failure is associated with Nrf2 Upregulation. Cardiovasc. Ther., 35 (5) (2017), Article e12277. 
Barber, LI \& Obinna-Echem, PC, 2016, 'Nutrient composition, physical and sensory properties of wheat-African walnut cookies', Sky Journal of Food Science 5(4), 24-30.

Belcher JD, McNamara JR, Grinstead GF, Rifai N, Warnick GR, Bachorik P, Frantz I (1991). Measurement of low density lipoprotein cholesterol concentration. In: Methods for Clinical laboratory Measurements of Lipid and Lipoprotein Risk Factors. Rifai N, Warnick GR (eds) AACC Press, Washington, 1991; pp 75-86.

Belcher JD, McNamara JR, Grinstead GF, Rifai N, Warnick GR, Bachorik P, Frantz I (1991). Measurement of low density lipoprotein cholesterol concentration. In: Methods for $\quad$ Clinical laboratory Measurements of Lipid and Lipoprotein Risk Factors. Rifai N, Warnick GR (eds) AACC Press, Washington, 1991; pp 75-86.

Benzer F, Kandemir FM, Ozkaraca $M$, Kucukler S, and Caglayan C, (2018). "Curcumin ameliorates doxorubicininduced cardiotoxicity by abrogation of inflammation, apoptosis, oxidative DNA damage, and protein oxidation in rats," Journal of Biochemical and Molecular Toxicology, vol. 32, no. 2, p. e22030.

Cappetta, D, De Angelis A, (2017). Oxidative stress and cellular response to doxorubicin: a common factor in the complex milieu of anthracycline cardiotoxicity. Oxid. Med. Cell Longev. 2017, 1521020. doi: 10.1155/2017/1521020.

Chen DB, Wang L, Wang PH (2000). Insulinlike growth factor I retards apoptotic signaling induced by ethanol in cardiomyocytes. Life Sci.;67:1683-1693.

Chikezie UN, 2017, 'Phytochemical and proximate composition of Tetracarpidium conophorum (African Walnut) seeds', International Journal of Research Studies in Biosciences 5(10), 25-31.

Chiu HC, Kovacs A, Blanton RM, Han X, Courtois $M$, Weinheimer $C J$, Yamada KA, Brunet $S, X \cup H$, Nerbonne JM, Welch MJ, Fettig NM, Sharp TL, Sambandam N, 1Olson KM, Ory DS, Schaffer JE (2005). Transgenic Expression of Fatty Acid Transport Protein 1 in the Heart Causes Lipotoxic Cardiomyopathy. Circ Res. February 4, 2005;96(2):225-233.

Dolinsky, VW, (2017). The role of sirtuins in mitochondrial function and doxorubicininduced cardiac dysfunction. Biol. Chem. 398, 955-974. doi: 10.1515/hsz-2016-0316.

Dominguez F, Cuenca S, Bilinska Z, Toro R, Villard E, Barriales-Villa R, Ochoa JP, Asselbergs $F$, Sammani A, Franaszczyk $M$, Akhtar M, Coronado-Albi MJ, Rangel-Sousa D, Rodriguez-Palomares JF, Jimenez-Jaimez J, Garcia-Pinilla JM, Ripoll-Vera T, Mogollon-Jimenez MV, Fontalba-Romero A, Garcia-Medina D, Palomino-Doza J, de Gonzalo-Calvo D, Cicerchia $M$, Salazar-Mendiguchia J, Salas C, Pankuweit S, Hey TM, Mogensen J, Barton PJ, Charron P, Elliott P, Garcia-Pavia P; European Genetic Cardiomyopathies Initiative Investigators, (2018). Dilated cardiomyopathy due to BLC2-associated 
athanogene 3 (BAG3) mutations. J Am Coll Cardiol. 2018; 72:2471-2481.

Edem CA, Dosunmu $\mathrm{Ml}$ and Bassey $\mathrm{FI}$ (2009). " Determination of proximate composition, ascorbic acid and heavy metal content of African walnut (Tetracarpidium conopho-rum)". Acad $R$ Int., 4(6): $501-512$.

El-Agamy DS, El-Harbi KM, Khoshhal S, (2019). Pristimerin protects against doxorubicin-induced cardiotoxicity and fibrosis through modulation of $\mathrm{Nrf2}$ and MAPK/NF-kB signaling pathways. Cancer Manage. Res., 11 (2019), p. 47.

El-Sayed ESM, Mansour AM, AbdulHameed MS, (2016). Thymol and carvacrol prevent doxorubicin-induced cardiotoxicity by abrogation of oxidative stress, inflammation, and apoptosis in rats. J. Biochem. Mol. Toxicol., 30 (1) (2016), pp. 37-44.

Ewer MS, Lippman SM (2005). Type ॥ chemotherapy-related cardiac dysfunction: time to recognize a new entity. J Clin Oncol.;23:2900-2902.

Ezealisiji MA, ljeomah SC and Agbo MO (2014). "Anti-ulcer activity of African walnut 'Tetracarpidium conophorum' nuts against gastric ulcers in rats". Asia Pac J Trop Dis., 4(1): 671-674.

Global Food book, 2015, 20 reasons you need the Africa walnut (Tetracrpidum conophorum), viewed 10 October 2017, from www.globalfoodbookreport.com.

Govender, J, Loos, B., Marais, E, Engelbrecht, AM (2018). Melatonin improves cardiac and mitochondrial function during doxorubicin-induced cardiotoxicity: a possible role for peroxisome proliferator-activated receptor gamma coactivator 1-alpha and sirtuin activity? Toxicol. Appl. Pharmacol. 358, 86101. doi: 10.1016/j.taap.2018.06.031.

Goyal, SN, C. Sharma, UB. Mahajan, CR. Patil, YO. Agrawal, S Kumari, DS. Arya, S Ojha (2015). Protective effects of cardamom in isoproterenol-induced myocardial infarction in rats. Int J Mol Sci 16: 27457-27469.

Hajra S, Patra AR, Basu A, (2018). Prevention of doxorubicin (DOX)-induced genotoxicity and cardiotoxicity: effect of plant derived small molecule indole-3carbinol (I3C) on oxidative stress and inflammation. Biomed. Pharmacother., 101 (2018), pp. 228-243.

Harbone JB (1996). Phytochemical methods. Chapman and Hall, London, pp: $52-105$.

Harbone JB (1996). Phytochemical methods. Chapman and Hall, London, pp: $52-105$.

Harbone JB (2005). Phytochemical Methods. New Delhi: Springer (India) Pvt.Ltd; 2005. p.17.

Hinderer C, Katz N, Buza EL, Dyer C, Goode T, Bell P, Richman LK, Wilson JM, (2018). Severe toxicity in nonhuman primates and piglets following high-dose intravenous administration of an adeno-associated 
virus vector expressing human SMN. Hum Gene Ther. 2018; 29:285-298.

Hitit, M, Corum, O, Corum, DDA (2018). cardioprotective role of Nerium oleander with the expression of hypoxia inducible factor 2A mRNA by increasing antioxidant enzymes in rat heart tissue. Acta Sci Vet. 2018;46(1):1560.

Horn M, Remkes, H, Strömer, Dienesch HC, and Neubaver S (2001). Chronic phosphocreatine Depletion by the Creatine Analogue Betaguanidinopropionate Is Associated With Increased Mortality and loss of ATP in Rats After Myocardial Infarction. Circulation.; 104:1844-1849.

Huang, CLaY, (2016). Chinese herbal medicine on cardiovascular diseases and the mechanisms of action. Front Pharmacol. 2016;7:469.

Ingwall JS, Weiss RG (2004). Is the failing heart energy starved? On using chemical energy to support cardiac function. Circ Res. Jul 23 2004;95(2):135-145.

Janick J and Paul RE (2008). "The encyclopedia of fruits and nuts". Oxfordshire: $C A B$ International.

Kaiserova $H$, Simunek T, Sterba $M$, denHartog GJ, Schroterova L, Poelova O (2007). New iron chelators in anthracyclininduced cardiotoxicity. Cardiovasc Toxicol;7:145-150.

Kauser, A, Shah, SMA, Iqbal, N. (2018). In vitro antioxidant and cytotoxic potential of methanolic extracts of selected indigenous medicinal plants. Prog Nutr. 2018;20(4):706712.

Kerkelä R, Grazette L, Yacobi R, lliescu C, Patten R, Beahm C, Walters B, Shevtsov S, Pesant S, Clubb FJ, Rosenzweig A, Salomon RN, Van Etten RA, Alroy J, Durand JB, Force $T$ (2006). Cardiotoxicity of the cancer therapeutic agent imatinib mesylate. Nat Med.;12:908-916.

Khattab HAH, El-Shitany NA, and Al-Lily AKS, (2016). "Effect of roselle (Hibiscus sabdariffa) against adriamycin inducedcardiotoxicity in male rats," The International Journal of Pharmaceutical Research and Allied Sciences, vol. 5, no. 3, pp. 519-534.

Knezevic T, Myers VD, Gordon J, Tilley DG, Sharp TE, Wang J, Khalili K, Cheung JY, Feldman AM, (2015). BAG3: a new player in the heart failure paradigm. Heart Fail Rev. 2015; 20:423-434.

Lin, JY and Tang CY (2007). Determination of total phenolic and flavonoid contents in selected fruits and vegetables, as well as their stimulatory effect on mouse splenocyte proliferation. Food Chem.101, 140-77.

Lin, JY and Tang CY (2007). Determination of total phenolic and flavonoid contents in selected fruits and vegetables, as well as their stimulatory effect on mouse splenocyte proliferation. Food Chem.101, 140-77. 
Loftsson T, Thorisdottir S (2009). "Enalaprilat and enalapril maleate eyedrops lower intraocular pressure in rabbits." Acta Ophthalmol.

Luo, H, Li, Y, Liu, B., Yang, Y, Xu ZD, (2017). MicroRNA-15b-5p targets ERK 1 to regulate proliferation and apoptosis in rat $\mathrm{PC} 12$ cells. Biomed. Pharmacother. 92, 10231029. doi: 10.1016/j.biopha.2017.05.140.

Ma H, Yang Y (2015). Enalapril. Sciencepub Researcher;7(1):64-78]. Brookdale University Hospital \& Medical Center, Brooklyn, New York 11212, USA(ISSN: 1553-9865).

Malu GO, Obochi C, Edem A and Nyong BE (2009)."Effects of methods of extraction on phytochemical con-stituents and antibacterial properties of Tetracarpidium conophorum seeds". Glob J Pure Appl Sci., 15 (3): $373-376$.

Mattila $M$, Koskenvuo J, Soderstrom $M$, Eerola K, Savontaus M, (2016). Intramyocardial injection of SERCA2a-expressing lentivirus improves myocardial function in doxorubicin-induced heart failure. J Gene Med. 2016; 18:124-133.

Maurea N, Coppola C, Piscopo G, (2016). "Pathophysiology of cardiotoxicity from target therapy and angiogenesis inhibitors," Journal of Cardiovascular Medicine, vol. 17, pp. e19-e26.

Minotti G, Menna P, Salvatorelli E, Cairo G, Gianni L (2004). Anthracyclines: molecular advances pharmacologic developments in antitumor activity and cardiotoxicity. Pharmacol Rev.;56:1 85-229. Moreno J, Villacastin J (2004). Intravenous enalapril does not prevent tachycardiainduced acute atrial electrical remodeling. Rev Esp Cardiol 57(4): 320-6.

Mridula, K, Parthibhan, S, Kumar, TS, Rao, M (2017). In vitro organogenesis from Tinospora cordifolia (Willd.) Miers-a highly valuable medicinal plant. S Afr J Bot. 2017;1 13:84-90.

Myers VD, McClung JM, Wang J, Tahrir FG, Gupta MK, Gordon J, Kontos CH, Khalili K, Cheung JY, Feldman AM, (2018). The multifunctional protein BAG3: a novel therapeutic target in cardiovascular disease. JACC Basic Transl Sci. 2018; 3:122131.

Nwaichi, EO, Osuoha, JO \& Monanu, MO, 2017, 'Nutraceutical potential of Tetracarpidium conophorum and Buccholzia coriacea in diet-induced hyperlipidemia', Journal of Chemical Health Risks 7(3), 157-170.

Obikili EN and Nwoye LO. Indices of obesity derived from weight and height. Nigerian Journal of Medicine, 2006; Jul-Sep : 219221.

Ogunyinka, BI, Oyinloye, BE, Adenowo, AF \& Kappo, AP, 2015, 'Potentials of some plant-derived foods in the management of diabetes and associated complications', African Journal of Traditional Complementary and Alternative Medicines 12(6), 12-20. http://doi.org/10.4314/Ajtcam.V12i6.2. 
Ohlig J, Henninger C, Zander S, (2018). Racl-mediated cardiac damage causes diastolic dysfunction in a mouse model of subacute doxorubicin-induced cardiotoxicity. Arch. Toxicol., 92 (1) (2018), pp. 441-453.

Okpero AO (2001). The Nutritive Value of Conophor Seed. University of Ibadan Press, Ibadan.

Olabinri BM, Eniyansoro OO, Okoronkwo CO, Olabinri PF and Olaleye MT (2010). "Evaluation of chelating ability of aqueous extract of Tetracarpidium conophorum (African walnut) in Vitro", Int J Appl Res Nat Proc., 3(3): $13-18$.

Onwuli DO, Brown H and Ozoani HA (2014). "Antihypergly-caemic effect

of Tetracarpidium conophorum nuts in alloxan induced diabetic female albino rats", ISRN Endocrinol, 2014: 1-4. article ID , 2014. Proesmans $W$ and Van Dyck M (2004). "Enalapril in children with Alport syndrome." Pediatr Nephrol 19(3): 27 1-5.

Ronald WD and James DF 2005. Embryology. $3^{\text {rd }}$ ed., Lippincott Williams \& Wilkins. Pg $31-41$.

Sahu, BD, Kumar, JM., Kuncha, M, Borkar RM, Srinivas, R, Sistla, R. (2016). Baicalein alleviates doxorubicin-induced cardiotoxicity via suppression of myocardial oxidative stress and apoptosis in mice. Life Sci. 144, 8-18. doi: 10.1016/j.Ifs.2015.11.018.
Schwab DM, Tilemann $L$, Baver $R$, Heckmann $M$, Jungmann $A$, Wagner $M$, Burgis J, Vettel C, Katus HA, El-Armouche A, Muller OJ, (2018). AAV-9 mediated phosphatase-1 inhibitor-1 overexpression improves cardiac contractility in unchallenged mice but is deleterious in pressure-overload. Gene Ther. 2018; 25:1319.

Shakya Manish, Paliwal Pankaj, Patil Swaraj, Koti BC, Swamy AHMV (2011). Effect of 'Qolest' a polyherbal formulation against doxorubicin induced cardiotoxicity in wistar rats. International Journal of Research in Pharmacy and Science, www.ijrpsonline.com. IJRPS 2011,1(3), 85100. ISSN: 2249-3522.

Simunek T, Sterba $M$, Popelová O, Adamcová M, Hrdina R, Gersi V (2009). Anthracycline induced cardiotoxicity: overview of studies examining the roles of oxidative stress and free cellular iron. Pharmacological Reports; 61 (1):154-171.

Sofowora A (1982). Medicinal plants and traditional medicine in africa. $1^{\text {st }}$ ed., John wiley and sons, Chichester, New York, ISBN10: 0471 103675, PP: 256.

Sofowora A (1982). Medicinal plants and traditional medicine in africa. $1^{\text {st }}$ ed., John wiley and sons, Chichester, New York, ISBN10: 0471103675, PP: 256.

Su F, Myers VD, Knezevic T, Wang J, Gao E, Madesh M, Tahrir FG, Gupta MK, Gordon J, Rabinowitz J, Ramsey FV, Tilley DG, Khalili K, Cheung JY, Feldman AM, (2016). 
Bcl-2-associated athanogene 3 protects the heart from ischemia/reperfusion injury. JCl Insight. 2016; 1:e90931.

Sun Z, Yan B, Yu WY, (2016). Vitexin attenuates acute doxorubicin cardiotoxicity in rats via the suppression of oxidative stress, inflammation and apoptosis and the activation of FOXO3a. Exp. Ther. Med., 12 (3) (2016), pp. 18791884.

Swain SM, Whaley FS, Ewer MS, (2003). Congestive heart failure in patients treated with doxorubicin: a retrospective analysis of three trials. Cancer.;97:2869-2879.

Tan, MCS, Oyong, GG, Shen, CC, Ragasa CY, (2016). Chemical constituents of Andrographis paniculata (Burm. F.) Nees. Int J Pharmacogn Phytochem Res. 2016:8:1398-1402.

Tang $\mathrm{YN}$, He XC, Ye $M$, Huang $\mathrm{H}$, Chen $\mathrm{HL}$, Peng WL, (2015). Cardioprotective effect of total saponins from three medicinal species of Dioscorea against isoprenalineinduced myocardial ischemia. J Ethnopharmacol. 2015;175:451-5.

Tang, F, Zhou, X, Wang, L, Shan, L, Li, C, Zhou, $\mathrm{H}$, (2018). A novel compound DT-010 protects against doxorubicin-induced cardiotoxicity in zebrafish and H9c2 cells by inhibiting reactive oxygen speciesmediated apoptotic and autophagic pathways. Eur. J. Pharmacol. 820, 86-96. doi: 10.1016/j.ejphar.2017.12.021.
Ten Hove M, Chan S, Lygate C, Monfared M, Boehm E, Hulbert K, Watkins H, Clarke K, Neubaver $S$ (2005). Mechanisms of creatine depletion in chronically failing rat heart. I Mol Cell Cardiol. Feb 2005;38(2):309-313.

Tietz NW (1995). Clinical Guide to Laboratory Tests, 3rd Edition. W.B. Saunders, Philadelphia, PA (1995).

Todd PA and Goa KL, (1992). "Enalapril. A reappraisal of its pharmacology and therapeutic use in hypertension." Drugs 43(3): 346-81.

Trease GE and Evans WC (2002). Pharmacognosy. 15 th ed., WB Saunders, London, ISBN: 8131200876, pp: 406.

Udedi SC, Ani ON, Anajekwu BN, Igwilo IO, Ononamadu CJ, Adindu CS, and Okafor UM, (2013). "Compara-tive proximate analyses of raw and cooked Tetracarpidium conophorum (African walnut) found in Awka, Anambra State, Nigeria", Biosci., 1(2): $114-118$.

Verma AK, Yadav, A, Dewangan, J, Singh, SV., Mishra, M, Singh, PK, (2015). Isoniazid prevents Nrf2 translocation by inhibiting ERK 1 phosphorylation and induces oxidative stress and apoptosis. Redox Biol. 6, 80-92. doi: 10.1016/j.redox.2015.06.020.

Wang, L, Li, Y, Deng, W (2018). Cardioprotection of ultrafine granular powder for Salvia miltiorrhiza Bunge against myocardial infarction. J Ethnopharmacol. 2018;222:99-106. 
Widyaningsih, W, Pramono S, Zulaela, Sugiyanto, Widyarini S, (2017) Protection by ethanolic extract from Ulva lactuca L. against acute myocardial infarction: antioxidant and antiapoptotic activities. Malays J Med Sci 24: 39-49.

Zhou Y, Zhong S, Hu S, (2018). Comparison of the effects of Shenfu injection and Shenmai injection on doxorubicin-induced chronic heart failure in rats. Int. J. Clin. Exp. Med., 11 (12) (2018), pp. 13169-13179.

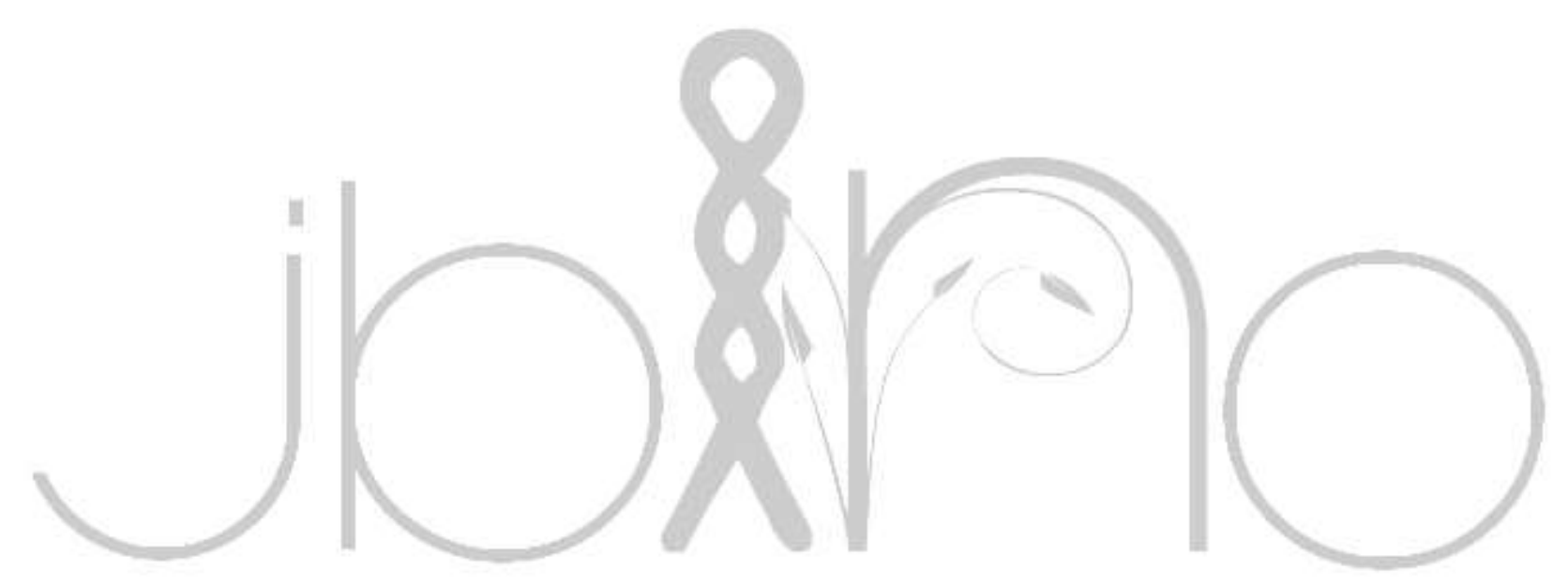

